
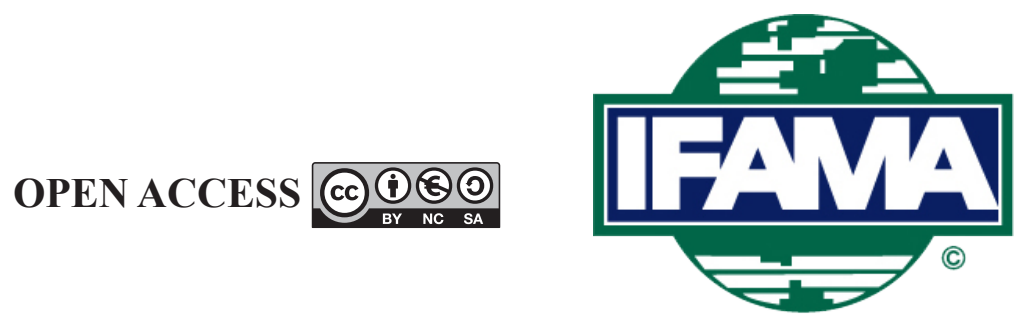

International Food and Agribusiness Management Review

Volume 21 Issue 8, 2018; DOI: 10.22434/IFAMR2018.0024

Received: 1 February 2018 / Accepted: 11 June 2018

\title{
Benefits and pitfalls of social capital for farmer cooperatives: evidence from China
}

RESEARCH ARTICLE

\author{
Yining $\mathrm{Xu}^{\mathrm{a}}$, Qiao Liang ${ }^{\oplus b}$, and Zuhui Huang ${ }^{\mathrm{c}}$ \\ ${ }^{a}$ PhD Candidate, ${ }^{b}$ Associated Professor, and ${ }^{c}$ Professor, China Academy for Rural Development, \\ School of Management, Zhejiang University, Yuhangtang Road 866, Hangzhou 310058, China P.R.
}

\begin{abstract}
This paper conducts an exploratory analysis on the role of social capital in influencing both economic and social performance of farmer cooperatives based on a sample of 156 farmers from 54 vegetable cooperatives in China's Hebei and Zhejiang provinces. Social capital is distinguished into bonding and bridging dimensions, with the former referring to the internal aspect of social capital and the latter the external "Guanxi" (meaning relationship) possessed by core members. The statistical results display that specific dimensions of social capital may not deliver the benefits expected by cooperative practitioners and academics. Both positive and negative effects of social capital on performances of farmer cooperatives are observed. To be specific, bonding social capital is positively associated with common members' economic benefits. Bridging social capital generates beneficial outcomes for the financial and social performances of cooperatives, while exhibiting negative influence on common members' income increase because of member heterogeneity.
\end{abstract}

Keywords: farmer cooperative, social capital, benefits, pitfalls JEL code: Q13

(i)Corresponding author: liangqiao2323@126.com 


\section{Introduction}

Rural areas in developing countries are characterized by several features challenging to economic growth, including poor infrastructure, physical distance to end market, technical incapability and relatively low education level of farmers. Numerous studies reveal that farmers could overcome these constrains by organizing themselves into cooperatives and acting collectively (Bernard et al., 2008; Staatz, 1987). A cooperative is defined by Dunn (1988) as 'a user-owned and controlled business form which benefits are derived and distributed on the basis of use'. The main activities of a farmer cooperative are providing technique services for members, bargaining for better prices, selling members' products, and so on (Feng and Hendrikse, 2012). These activities benefits members by economic scale, risk reduction, the establishment of countervailing power, value added from processing, auxiliary services for members, and assurance of product outlet, etc. (Cook, 1995; Ito et al., 2012; Yang et al., 2013).

In addition to the economic functions mentioned above, many cooperatives act similarly to associations and provide services such as speaking with the governments as representatives of farmers, reduce the problems of the feminization and ageing of the agricultural workforce, and so on (Liang and Hendrikse, 2013; Song and Vernooy, 2010). This diversity of the roles adds to even more importance of cooperatives in the social and economic development in agriculture.

However, the collective ownership and decision-making process of cooperatives tend to result in high governance costs. Just as Valentinov (2004) puts that, cooperatives are social capital-based organizations due to the high involvement and interaction among members during decision making. Social capital, facilitating cooperation and information exchange, has a special role in cooperatives. Social capital is broadly defined as a valuable asset based on inter-personal social relationship (Adler and Kwon, 2002).

Cooperatives in China have a couple of distinguished features from those in the western world. One feature lies in Guanxi culture, the Chinese form of relationship management (Jia and Zsidisin, 2014). It refers to the relation mechanism bonding exchange partners and is the major informal institution in China, which makes social capital even more important in Chinese cooperatives (Jia and Zsidisin, 2014; Liang et al., 2015a). People use their "Guanxi" to facilitate activities such as transactions in business and acquirement of resources. Farmer cooperatives in China are usually small and embedded in local villages, thus, the "Guanxi" may on the one hand benefit communication and on the other hand hinder external resources (Liang and Hendrikse, 2013).

The other is the heterogeneity of members in cooperatives. The distinction of core and common members is recognized, with the former dominant in both control and income rights while the latter specializes in production but hardly takes part in decision making (Liang et al., 2015b). The heterogeneity of the membership, on the one hand, requires a higher demand of social capital to coordinate between alternative groups of members; whereas, on the other hand, it may cause benefits brought by the social capital unevenly allocated between core and common members.

This paper, therefore, distinguishes different dimensions of social capital for both core and common members, investigated the benefits and pitfalls of various social capital components for the economic and non-economic performances in Chinese cooperative context. There are several ways to position this research in the literature of social capital and cooperative. First, this paper is among the first to incorporate the diverse compositions of social capital possessed by different types of members, i.e. core and common members, in cooperatives. Although the research in social capital of cooperatives is growing, most studies focus on part or specific aspects of social capital. Second, this paper provides s special interest to the pitfalls of social capital, beyond its benefits. The benefits of social capital are broadly investigated in the previous research, yet little attention is given to the pitfalls of social capital. Third, this paper attempts to address the multiple performances of cooperatives. Since a cooperative has simultaneous economic and non-economic objectives, it should not be studied from the perspective of one or the other in isolation. 
The rest of the paper is organized in the following way. Theories with regard to social capital and cooperative performance are addressed in Section 2. Section 3 is dedicated to the methodology, while the results are presented in Section 4 and followed by a discussion in Section 5. Section 6 concludes.

\section{Social capital and farmer cooperatives}

This section defines social capital and identifies its composition (2.1) and analyses the benefits and pitfalls of social capital (2.2 and 2.3). A review of the literature regarding social capital in farmer cooperative is provided in Section 2.4 .

\subsection{Definition and composition of social capital}

The study of social capital initiated in the macro level and has been applied in the micro level in the last decade. Social capital is defined and studied in multiple disciplines such as political economics, sociology, organizational economics, business management, and so on. From the perspective of analytical levels, social capital has been investigated ranging from the region and nation level social capital (Knack and Keefer, 1997; Malecki, 2012; Putnam, 1995) to communities (Cooke et al., 2005; Hayami, 2009), organizations including firms (Arregle et al., 2007; Belliveau et al., 1996; Cooke and Wills, 1999; Liang et al., 2015a; Nahapiet and Ghoshal, 1998), and even families and individuals (Pearson et al., 2008; Westlund and Gawell, 2012). Its definition therefore varies broadly across different domains and analytical levels. For example, social capital at the individual level is defined by Burt (1992) as "friends, colleagues, and more general contacts through whom you receive opportunities to use your financial and human capital", while Putnam (1995) defines macro-level social capital as "networks, norms, and social trust that facilitate coordination and cooperation for mutual benefits." At the organizational level, "social capital is the goodwill available to individuals or groups. Its source lies in the structure and content of the actor's social relations" (Adler and Kwon, 2002). Hence, it is a jointly owned good as opposed to individually possessed financial or human capital.

Due to the complexity of social capital, ingredients of social capital are demonstrated to make it more understandable and measurable. There are two ways commonly adopted to recognize the ingredients of social capital in business and management studies at the organizational level. One is illustrated by Tsai and Ghoshal (1998) who recognize three dimensions of social capital, i.e. structural, relational, and cognitive dimensions of social capital. The structural social capital pertains to the social networks or social interactions of an organization that can be used to access resources or facilitate transactions. The relational social capital refers to the trust as well as trustworthiness that are embedded in the organization or among its members. The cognitive social capital addresses the shared vision among members of an organization that contributes to collective orientation and action.

The distinction between bridging and bonding social capital, also known as external and internal social capital, is adopted by many scholars as well. Bridging social capital is the external relations with heterogeneous groups, while bonding social capital refers to the ties among members within a group or an organization (Adler and Kwon, 2002). The distinction of bridging and bonding social capital is relative and not fixed. For example, a firm's linkages with other firms in the market are considered to be bridging social capital from the perspective of firm employees, whereas they are regarded as bonding social capital if firm communities or institutions are the unit of analysis. This paper adopts the view of bridging and bonding social capital.

\subsection{Benefits of social capital in organizations}

One of the sources of an organization's competitive advantage resides in social capital. Intra-organizational bridging social capital facilitates information exchange and resource flow, saves transaction costs, and motivates product innovation (Knack and Keefer, 1997; Pennings et al., 1998; Robison et al., 2002; Schiele et al., 2015). To put it in another way, it reduces the risk of opportunism and maintains smooth cooperation 
(Lins et al., 2017; Raub and Weessie 1990). As Nahapiet and Ghoshal (1998:252) stress, the information one possesses determines the resources available.

Bonding social capital within organizations positively influences the intellectual capital creation, commitment justification, and work flexibility (Nahapiet and Ghoshal, 1998; Pearson et al., 2008). The productive potential of social capital lies in its ability to promote the building of human capital or intellectual capital (Florin et al., 2003; Semrau and Hopp, 2016). Ties among organization members can facilitate coordination of tasks and overcome the dilemmas of cooperation (Gargiulo and Benassi, 2000). Edelman et al. (2004) express a similar view, arguing that social capital can give members a sense of cohesion and identity. Members therefore tend to be committed to the organization featured by a high level of social capital. In addition, fewer contracts are needed to maintain the cooperation and there is more flexibility.

\subsection{Pitfalls of social capital in organizations}

Besides the more-is-better argument, drawbacks of social capital for organizations are noticed by a few scholars as well. Adler and Kwon (2002) indicate that social capital is beneficial and concurrently detrimental. The disadvantages of using social capital lie in three dimensions of risks. First, over-investment in creating and maintaining social capital may happen if a firm is over-committed to some relationships. The creation of social capital may also exert excessive claims on successful members by others within a network (Portes, 2014). Hence, social capital investment may be cost inefficient, since it is costly to maintain some ties. In addition, Hanses (1993) finds that it takes longer for project teams strongly tied, compared to relatively weakly tied, with others to complete a task.

Second, the exclusionary effects of close networks result in the localization of ties and limit the diversity of networks. The strong identification of members in a network causes the fragmentation of the whole and consequently results in dependence-oriented culture (Eklinder-Frick et al., 2011, 2012) and low efficiency of information exchange. Opportunities of broader collaboration may be missed as well. Granovetter (1985) and Gargiulo and Benassi (2000) stresses that strongly tied links between traders cause relation closure and little autonomy to negotiate. Such links hinder, rather than help, organization performance. Conversely, those who are not engaged in strongly linked social networks have more opportunities to look for traders or pursue more favorable terms. For one thing, the inflow of information may be hampered by the closure. Locke et al. (1999) recognizes the danger of utilizing social capital, such as the loss of useful information and communication with stakeholders outside the network. He stresses that "strong personal bonds between executives can facilitate communication between those executives but, for the same reason, can isolate those who do not have such bonds." For another thing, possible downsides of social capital also lie in the negative externalities, i.e. closure of the network hampers the outflow of valuable information to broader stakeholders (Adler and Kwon, 2002).

Third, the solidarity benefits of social capital may hinder the generation of new ideas and innovation in firms. The membership in some network simultaneously causes exclusion of new knowledge from other sources and impedes the adoption of innovations (Edelman et al., 2004; Portes and Sensenbrenner, 1993; Weber and Weber, 2011). Over-embeddedness in communities or networks can result in inertia in adopting or creating novel ideas (Gargiulo and Bernassi, 1999). Besides, social capital in closely tied networks may cause free-riding problems and hinder entrepreneurial ideas (Portes, 2014). These potential pitfalls of social capital may result in negative consequence of performance.

\subsection{Social capital in farmer cooperatives}

In spite of the broad investigation of social capital in firms, corresponding research for cooperatives is relatively limited. Exceptions are Valentinov (2004), Nilsson et al., 2012; Ruben and Heras (2012), and Liang et al. (2015a). Valentinov (2004) is the first to define and demonstrate the role of social capital in cooperatives. Nilsson et al. (2012) argue that cooperatives are losing social capital because of their economic orientation. 
A few studies based on data from different sectors and countries/regions also confirm the positive impact of social capital on economic performance of cooperatives. Ruben and Heras (2012) and Liang et al. (2015a) investigate the role of social capital based on empirical evidence from Ethiopian coffee cooperatives and Chinese vegetable \& fruit cooperatives, respectively.

A cooperative is an entity based on vertical integration of a heterogeneous membership. Social capital possessed by different groups of members might be different. Core members in a Chinese cooperative use their external "Guanxi" to seek for better market opportunities and obtain resources from the government, and meanwhile coordinate members to provide qualified products (Liang and Hendrikse, 2013). Common members exchange information with managers and other members of the cooperative, but have little "Guanxi" for external resources (Liang et al., 2015a). A thorough study on various aspects of social capital possessed by alternative groups of members in farmer cooperatives, and both the positive and negative effects of these social capital components is desirable.

\section{Methodology}

This section delineates the sample used in the statistical analysis, illustrates the measurement of dependent, independent, and control variables, and establishes the statistical model.

\subsection{Sample}

Cooperatives in China mostly emerged in 2000s and have been experiencing a rapid growth since 2007 in which year the national Cooperative Law was promulgated. There were 26,400 farmer cooperatives in 2007 and the number increased to 1.93 million by the end of July $2017 .{ }^{1}$ We limit the population to vegetable cooperatives to control for the heterogeneity of cooperatives related to products. The communication and relationships between members, and between managers and external stakeholders in production and marketing vary among different sectors due to product attributes, which results in different stocks of social capital in cooperatives. Performance of cooperatives is largely dependent on the product as well. Vegetable cooperatives in China provides members with inputs and technology services, collect products from farmers, and deliver to wholesale markets, retailers, or directly to consumers. Some cooperatives additionally conduct first-stage processing, such as grading and packing, and/or secondary processing. They are supposed to have advantages in vertical integration, quality enhancement, and value adding.

A multistage sampling procedure is used to choose cooperatives to be surveyed. First, we purposely selected Hebei and Zhejiang provinces as the sampling areas based on the production intensity and target markets. Hebei is one of the largest provinces in terms of vegetable production. ${ }^{2}$ Zhejiang is the main vegetable producing area for the Yangtze River Delta region of China. Farmer cooperatives play a key role in helping farmers sell vegetables to the market in these two provinces. There were 13,622 vegetable cooperatives in Hebei and 6,113 in Zhejiang, both of which are among the largest provinces in terms of the vegetable cooperative quantity. Furthermore, the market environment and value chain assignment of the two provinces are different (Huang et al., 2008), which may have influence on both social capital and its role on the performance of cooperatives.

In the second stage, a pre-investigation of vegetable cooperatives was conducted in Hebei and Zhejiang in August, 2014. Face-to-face interviews were done with officials from various governmental departments responsible for the regulation of the vegetable sector to obtain an overview of vegetable production and marketing in the local province. We then visited a few vegetable cooperatives and interviewed both chairpersons

\footnotetext{
1 The data were collected from the official website of the State Administration for Industry and Commerce which organization existed before March 2018 and then was merged with part of the department from the other two governmental organizations, i.e. State Administration for Quality Supervision and Inspection and Quarantine and China Food and Drug Administration, and formed a new organization named State Administration for Market Regulation. The data can be accessed via the link: http://samr.saic.gov.cn.

${ }^{2}$ Data source: Hebei Rural Statistics Yearbook 2014. China Statistics Press, 2015.
} 
and members to pre-test the structured questionnaires. The questionnaires were revised for several times based on multiple pre-tests. Based on respondents' feedback, we choose items which are understandable and highly responded.

Third, twelve prefectures in Hebei and Zhejiang were chosen according to the production intensity and vegetable varieties. The formal survey was carried out during July to September, 2015. We randomly chose 57 villages having vegetable cooperatives and surveyed a vegetable cooperative in each of the villages. For each cooperative, we first interviewed the chairperson, using the structured questionnaire, to obtain organizational level data; and then we surveyed three to four common members from each cooperative to collect individual level data and confirm the reliability of chairperson's answers. Both chairpersons and members were interviewed face-to-face privately between the interviewee and interviewer, either at the cooperative office or a member's farm. Three cooperative questionnaires and quite a few member questionnaires were abandoned due to the lack of important information. We finally obtained a database consisting of 156 farmers from 54 cooperatives.

\subsection{Measure}

\section{- Performance}

Unlike for-profit firms which pursue only financial goals, cooperatives have dual attributes comprised of an economic attribute and a social attribute. Both economic benefits and non-economic purposes such as social evaluation are objectives of cooperatives. However, researchers tend to neglect the non-economic dimension, because of the difficulty in measuring the latter or the unavailability of data. We adopt a more inclusive approach developed in Franken and Cook (2015) to evaluate cooperative performance in terms of multiple facets.

Cooperatives' economic performance could be integrally evaluated at both the member level and organizational level. The former is measured by members' evaluation on the increase of agricultural income due to the membership. We choose this indicator rather than farmers' factual income for two reasons. First, cooperatives play a more significant role in increasing the income of low income farmers than high income farmers (Markelova et al., 2009). Low income members are more dependent on cooperatives due to the less professional production and weaker position in the market. If we use the members' income, it may underestimate cooperatives' influence in increasing smaller farmers' income. Second, members' unobservable characteristics may cause endogeneity and simultaneous causality problem between income and social capital. We cannot control this problem with the cross-sectional data from the survey. Therefore, members' subjective evaluation on the income increase after they join the cooperative would be a better indicator to measure the cooperatives' economic performance at the member level. The organizational level economic performance is measured by cooperatives' net profit last year.

Cooperatives' social performance is measured by the cooperatives' identity rating, which is awarded by the authority. When grading the identity of a farmer cooperative, the authority evaluates mainly the following facets: (1) the capability of serving members as well as local non-member farmers; (2) normative management as a cooperative; (3) standardized production and food safety control; (4) brand construction and certificates of green and organic products; (5) access to broad market and decreasing the local price fluctuation. Identity rating is a comprehensive index indicating the social influence and the social image of a farmer cooperative to its stakeholders. Due to the formal publication of the list of demonstration cooperatives every year by the government, it is regarded as an effective indicator of cooperatives' social contributions. There are five levels of identity rating, the state, provincial, prefectural, county level demonstration cooperatives, and common cooperatives. The five facets of identity rating the authority uses may be correlated to the scale and revenue of cooperative and influence members' income, thus we need checking the correlation problem among the three performance indicators before doing regression. The statistic result shows that there is no significant relationship among them. 
To sum up, three performance indicators are taken as dependent variables. They are members' evaluation on agricultural income increase, cooperatives' net profit, and cooperatives' identity rating, among which the former two representing economic and the third representing social performances of cooperatives. The definition of each variable is presented in Table 1.

Table 1. Variable and items defining and measurement.

\begin{tabular}{|c|c|c|}
\hline Variable & Definition & Measurement \\
\hline Income increase & $\begin{array}{l}\text { Members' income increased due to the } \\
\text { membership of the cooperative }\end{array}$ & Very small 12345 Very large \\
\hline Net profit & The cooperative's net profit last year & 10,000 yuan \\
\hline Identity rating & The cooperative's identity rank & $\begin{array}{l}1=\text { Common cooperative } \\
2=\text { County-level demonstration cooperative } \\
3=\text { Prefectural demonstration cooperative } \\
4=\text { Provincial demonstration cooperative } \\
5=\text { National demonstration cooperative }\end{array}$ \\
\hline Info_share_1 & $\begin{array}{l}\text { Members frequently share technical or } \\
\text { market information with others }\end{array}$ & Disagree 12345 Agree \\
\hline Info_share_2 & $\begin{array}{l}\text { The cooperative frequently organizes } \\
\text { technical training meetings }\end{array}$ & Disagree 12345 Agree \\
\hline Info_share_3 & $\begin{array}{l}\text { It is easy to get the market or technical } \\
\text { information }\end{array}$ & Disagree 12345 Agree \\
\hline Info_share_individual & $\begin{array}{l}\text { The mean value of info_share_1, info_ } \\
\text { share_2 and info_share_3 }\end{array}$ & \\
\hline Info_share_cooperative & $\begin{array}{l}\text { The mean value of info_share_individual } \\
\text { within the cooperative }\end{array}$ & \\
\hline Trust_1 & $\begin{array}{l}\text { I believe the chairperson always takes } \\
\text { members' benefits into consideration }\end{array}$ & Disagree 12345 Agree \\
\hline Trust_2 & $\begin{array}{l}\text { I believe the chairperson does not doubt my } \\
\text { loyalty and commitment }\end{array}$ & Disagree 12345 Agree \\
\hline Trust 3 & The chairperson and I trust each other & Disagree 12345 Agree \\
\hline Trust 4 & Members trust each other & Disagree 12345 Agree \\
\hline Trust_individual & $\begin{array}{l}\text { The mean value of trust_1, trust_2, trust_3 } \\
\text { and trust } 4\end{array}$ & \\
\hline Trust_cooperative & $\begin{array}{l}\text { The mean value of trust_indivudual within } \\
\text { the cooperative }\end{array}$ & \\
\hline Goal_1 & I know the common goal of our cooperative & Disagree 12345 Agree \\
\hline Goal_2 & All the members fight for the common goal & Disagree 12345 Agree \\
\hline Goal_individual & The mean value of goal_1 and goal_2 & \\
\hline Goal_cooperative & $\begin{array}{l}\text { The mean value of goal_individual within the } \\
\text { cooperative }\end{array}$ & \\
\hline Supplier & $\begin{array}{l}\text { The number of linked suppliers by the } \\
\text { chairperson }\end{array}$ & \\
\hline Buyer & $\begin{array}{l}\text { The number of linked buyers by the } \\
\text { chairperson }\end{array}$ & \\
\hline Bank staffs & $\begin{array}{l}\text { The number of linked financial employees by } \\
\text { the chairperson }\end{array}$ & \\
\hline Government & $\begin{array}{l}\text { The chairperson's closeness with the } \\
\text { government }\end{array}$ & Distant 12345 Very close \\
\hline Location & Province where the cooperative is located & 1=Zhejiang, $0=$ Hebei \\
\hline
\end{tabular}


Table 1. Continued.

\begin{tabular}{|c|c|c|}
\hline Variable & Definition & Measurement \\
\hline Coop age & The age of cooperative & Years \\
\hline Membersize & Total number of members & Number of members \\
\hline Decision_making & $\begin{array}{l}\text { Decision making right in general meeting is } \\
\text { based on one-person-one-vote }\end{array}$ & $\begin{array}{l}1=\text { One person one vote, } 0=\text { One share one } \\
\text { vote or hybrid rule }\end{array}$ \\
\hline Chair_age & Age of the chairperson & Years \\
\hline Chair_edu & Education level of the chairperson & $\begin{array}{l}1=I l l i t e r a c y \\
2=\text { Primary level } \\
3=\text { Junior high school level } \\
4=\text { Senior high school level } \\
5=\text { College level and above }\end{array}$ \\
\hline Member_age & Age of the member & Years \\
\hline Member_edu & Education level of the member & $\begin{array}{l}1=I l l i t e r a c y \\
2=\text { Primary level } \\
3=\text { Junior high school level } \\
4=\text { Senior high school level } \\
5=\text { College level and above }\end{array}$ \\
\hline Mem veg year & Members'vegetable planting experience & Years \\
\hline
\end{tabular}

\section{- Social capital}

Due to the complexity of social capital, we subdivide bonding and bridging social capitals into more detailed ingredients based on the literature review, so as to develop a more comprehensive explanation for both the pros and cons of social capital.

Bonding social capital is the ties among members within a cooperative. It binds members and makes collective action function in the form of a sense of information and knowledge exchange (Gargiulo and Benassi, 2000), trust (Cohen and Prusak, 2001), and cohesion and shared value (Edelman et al., 2004). Hence, three variables, information sharing, trust, common goal are developed to measuring the bonding social capital. As all of these variables are subjective, we use a Likert Five-Point Scale to measure them. Each variable is indicated by three to four items in the questionnaire for members, all of which are presented in Table 1. We check the reliability, unidimensionality and validity of these items. Factor analysis shows that items indicating the same variable have been loaded in the same dimension with high loading. However, one item of common goal has a cross-loading problem. We therefore drop it and have two items to score the common goal. Other items are unidimensional with high validity. The reliability test shows that Cronbach's alpha of information sharing, trust, and common goal are respectively $0.678,0.812$, and 0.824 , implying a high reliability of all the three variables. Based on these tests, we average respondent's scores for the items indicating the same variable and get three scores, i.e. information sharing, trust, and common goal at the member level. Then, we test the interrater reliability and interrater agreement of them. ICC (1)s (reliability of score within group) are over 0.3 , and ICC (2) (reliability of mean group score) of the three average scores are over 0.7, both of which meet the requirement of variables in the organizational research. Sequentially, we compute the mean of members' scores for each variable to obtain the organizational level score. Scores of the three bonding social capital variables at the organizational level are finally obtained.

Bridging social capital captures the intra-organization relationships, so it is explicitly specified by core members" "Guanxi" with external stakeholders (Leana and Pil, 2006). External stakeholders of farmer cooperatives are upstream inputs suppliers, downstream products buyers, banks, and the government. We develop four variables to measure cooperatives' bridging social capital. They are the number of tied suppliers, tied buyers and tied bank staffs, and the closeness of the "Guanxi" with the government that core members 
have. Generally, bridging social capital is held by top managers (Leana and Pil, 2006). The cooperative's chairperson is the key person who connects the organization and the outside stakeholders, hence, indicators of bridging social capital are specified by chairpersons' links with the four types of stakeholders.

\section{- Control variables}

Cooperatives' characteristics, such as location, age, size, governance factors, and managerial factors are also associated with the success and performance of the cooperative (Banaszak, 2008; Dejene and Regasa, 2015; Liang et al., 2015a; Sexton and Iskow, 1988). Regional differences are represented by the dummy province. Governance factors are specified by the decision-making rights distribution. We use a dummy variable to represent alternative decision-making rules in the general meeting, one-person-one-vote, or otherwise. Managerial factors contain chairpersons' age and education. Farmers' demographic characteristics like their age, education and vegetable planting experience may influence members' income. A multicollinearity check for the controlling variables has been conducted before the estimation of regression model. No multicollinearity problem is found.

\subsection{Model}

Income increased, among the three performance indicators, is a member level indicator, while the cooperative's social capital is the organizational level variable. In order to capture the dependency of members within the cooperative and separate its influence from individual factors, we adopt the two-level hierarchical Linear Model (HLM). HLM is an appropriate method to analyze the cross-level data, for example, farmers embedded in cooperatives.

The other two performance indicators, net profit and identity rating, are measured at the organizational level. The effect of net profit on social capital is estimated by Ordinary Least Squares Regression, while that of identity rating on social capital is calculated by Ordered Probit Regression.

\section{Results}

Table 2 displays the descriptive statistics of each variable, including the mean, minimum, maximum, and standard deviation values. The distribution range of both cooperatives' net profit, members' income increased and cooperatives' identity rating covers a broad scope. Information sharing within cooperative is 3.71 , which is a little higher than the medium. Trust within the cooperative is 4.24 , which is high compared with other bonding social capital indicators. Awareness of the common goals of their cooperatives is scored at 3.61. Cooperatives have 3.17 linked suppliers, 9.78 linked buyers, and 1.37 linked persons working in banks on average. Cooperative chairpersons' closeness with the government is evaluated by 3.67, representing a relatively high level of closeness between chairpersons and the government.

Table 3 displays the influences of social capital on cooperative performance. The statistical results demonstrate that specific dimensions of social capital may not deliver the benefits expected by cooperative practitioners and academics. First, both positive and negative effects of social capital on performances of farmer cooperatives are observed. Bonding social capital has significantly positive effects on common members' income increase and the cooperative's identity rating. Some bridging social capital indicators are negatively correlated with common members' income increase, while some are positively with the net profit and identity rating of cooperatives. Second, bonding social capital plays a more important role in common members' economic benefits, while bridging social capital is more helpful in organizational economic and social performance.

Among cooperative characteristics, the location influences the economic performance. Cooperatives located in Heibei have higher net profit than cooperative in Zhejiang. Cooperatives with a longer history basically perform better than the younger peers in increasing members' income and identity rating. Cooperatives with larger membership sizes obtain higher identity ratings. Cooperatives adopting "one person one vote" 
Table 2. Descriptive statistics of variables.

\begin{tabular}{llllll}
\hline & Variable & Mean & S.D. & Min & Max \\
\hline Performance variables & Income increased & 3.34 & 1.308 & 1 & 5 \\
& Net profit & 92.06 & 160.56 & -200 & 700 \\
& Identity rating & 3.30 & 1.297 & 1 & 5 \\
Social capital variables & Info_share_cooperative & 3.71 & 0.667 & 1.83 & 4.78 \\
& Trust_cooperative & 4.24 & 0.55 & 2.63 & 5 \\
& Goal_cooperative & 3.61 & 0.792 & 1.33 & 4.67 \\
& Supplier & 3.17 & 3.994 & 0 & 30 \\
& Buyer & 9.78 & 15.953 & 0 & 100 \\
& Bank staffs & 1.37 & 1.570 & 0 & 6 \\
Control variables & 3.67 & 1.303 & 1 & 5 \\
& Government & 0.65 & 0.482 & 0 & 1 \\
& Location & 8.41 & 3.300 & 3 & 16 \\
& Cooperative age & 114.61 & 199.993 & 5 & 1,318 \\
& Membersize & 0.52 & 0.504 & 0 & 1 \\
& Decision_making & 47.22 & 7.654 & 30 & 62 \\
& Chair_age & 3.85 & 0.899 & 1 & 5 \\
& Chair_edu & 48.63 & 10.216 & 25 & 78 \\
& Member_age & 2.93 & 0.828 & 1 & 5 \\
& Member_edu & 14.53 & 10.699 & 0 & 50 \\
\hline
\end{tabular}

Table 3. The influences of social capital on cooperative performance. ${ }^{1}$

\begin{tabular}{|c|c|c|c|c|c|c|}
\hline \multirow[t]{2}{*}{ Variables } & \multicolumn{2}{|l|}{$\begin{array}{l}\text { (1) } \\
\text { Income increase }\end{array}$} & \multicolumn{2}{|l|}{$\begin{array}{l}(2) \\
\text { Net profit }\end{array}$} & \multicolumn{2}{|l|}{$\begin{array}{l}\text { (3) } \\
\text { Identity rating } \\
\end{array}$} \\
\hline & Coefficient & S.E. & Coefficient & S.E. & Coefficient & S.E. \\
\hline \multicolumn{7}{|l|}{ Bonding social capital } \\
\hline Info_aggregate & $0.384^{* *}(3.27)$ & 0.0987 & $-14.690(-0.40)$ & 36.6259 & $-0.193(-0.52)$ & 0.3704 \\
\hline Trust_aggregate & $0.368^{* *}(2.70)$ & 0.1360 & $7.911(0.19)$ & 42.2941 & $-0.330(-0.80)$ & 0.4142 \\
\hline Goal_aggregate & $0.205^{*}(2.08)$ & 0.1175 & $-29.220(-1.31)$ & 22.2901 & $0.717^{* *}(2.95)$ & 0.2344 \\
\hline \multicolumn{7}{|l|}{ Bridging social capital } \\
\hline Supplier & $-0.023(-0.88)$ & 0.0261 & $2.457(0.56)$ & 4.3636 & $-0.045(-0.91)$ & 0.0450 \\
\hline Buyer & $-0.015^{*}(-2.33)$ & 0.0066 & $0.633(0.57)$ & 1.1145 & $0.021(1.87)^{* * *}$ & 0.0112 \\
\hline Bank staffs & $0.046(0.67)$ & 0.0683 & $34.980^{* *}(2.95)$ & 11.8445 & $0.210(1.48)$ & 0.1416 \\
\hline Government & $0.104(1.23)$ & 0.0840 & $37.870 *(2.70)$ & 14.0334 & $0.791^{* * *}(4.39)$ & 0.1799 \\
\hline \multicolumn{7}{|l|}{ Control variables } \\
\hline Location & $-0.360(-1.21)$ & 0.2990 & $-146.200^{* *}(-2.85)$ & 6.5482 & $-0.293(-0.57)$ & 0.5164 \\
\hline Coop_age & $0.078 *(1.96)$ & 0.0407 & $-5.116(-0.78)$ & 0.0911 & $0.126(1.79)^{* * *}$ & 0.0703 \\
\hline Member_size & $0.0001(0.22)$ & 0.0005 & $-0.003(-0.03)$ & 37.3385 & $0.003^{* *}(2.60)$ & 0.0010 \\
\hline Decisionmaking & $-0.195(-0.90)$ & 0.2156 & $44.96(1.20)$ & 2.4417 & $-1.098^{* *}(-2.73)$ & 0.4016 \\
\hline Mana_age & $-0.016(-1.08)$ & 0.0147 & $5.303^{*}(2.17)$ & 23.0782 & $-0.010(-0.38)$ & 0.0252 \\
\hline Mana_edu & $-0.345^{* *}(-2.61)$ & 0.1323 & $-5.385(-0.23)$ & 51.2336 & $0.391(1.67)^{* * *}$ & 0.2345 \\
\hline Mem_age & $0.011(1.09)$ & 0.0104 & & & & \\
\hline Mem_edu & $0.208(1.78)$ & 0.1173 & & & & \\
\hline Mem_veg_year & $-0.011(-1.23)$ & 0.0092 & & & & \\
\hline \multicolumn{2}{|c|}{ Level 1 number of observations } & 156 & & & & \\
\hline \multicolumn{2}{|c|}{ Level 2 number of observations } & 54 & & 54 & & 54 \\
\hline
\end{tabular}

$1^{* * *},{ }^{* *}$ and $^{*}$ represent $P<0.001, P<0.01$ and $P<0.05$ respectively, with $t$-values in parentheses. 
decision-making rule tend to have lower identity ratings. Generally older chairpersons perform better in terms of cooperatives' net profit. Chairpersons' education is positively associated with the cooperative's identity rating, while exhibiting a negative effect on members' income increase.

\section{Discussion}

\subsection{Bonding social capital and cooperative performance}

Bonding social capital plays an important role from the perspective of individual members. All the bonding social capital variables, information sharing, trust, and members' common goals, have significantly positive effect on members' income increase. Nilsson et al. (2012) indicate that the function of social capital within an organization may vary along alternative life cycle stages of cooperatives, yet most probably is positive. Our estimation basically confirms Nilsson et al. (2012), but has some episodes. In general, bonding social capital has positive effects on members' income increase and cooperatives' identity rating, while exert no significant influence on net profit of cooperatives.

Technology and market information sharing exhibits significant and positive effect on members' income increase. Cooperatives are formed to promote the innovation and adoption of production technology, and gain market access and value added (Abebaw and Haile, 2013; Ito et al., 2012; Jia et al., 2012). The realization of these functions is dependent on efficient information sharing within cooperatives. Farmers in China are characterized by the disparity of entrepreneurial and common farmers (Liang et al., 2015b). The former type of farmers are mostly cooperative managers and farming technology experts. Common farmers rely on entrepreneurial farmers to adopt advanced technology and get access to market information, which contributes to their income increase. Nevertheless, trainings of technology and market information do not generate benefits in terms of cooperatives' net profits and identity rating.

Our results, that trust in cooperatives has a positive impact on farmers' economic performance, are consistent with the evidence from many previous studies. Trust reduces coordination costs and facilitates the pursuit of collective goals (Tsai and Ghoshal, 1998). When individuals trust each other, they are more likely to cooperate and participate in collective actions (Gulati, 1995; Nilsson, et al., 2012). In addition, trust helps to reduce agent problems and lead to efficient control (Søgaard, 1994). The interesting thing is that trust within a cooperative does not help to enhance the economic or social performance of the cooperative. Managers of a cooperative take care of the interests of both the organization and members, and these two streams of interests are not always consistent.

Members' awareness of a common goal positively influences members' economic performance and cooperative social influence. Cooperatives are faced with the challenge of a common goal awareness by members as they undergo the transformation to be more market-oriented and members produce more differentiated products (Fulton, 1999). Heterogeneity of members causes different objective functions between members, which consequently leads to inefficiency. Though core members play an essential role in Chinese farmer cooperatives, they depend on common members to deliver products in order to obtain scale economies and sustain stable provision of products (Liang et al., 2015b). Members being aware of common goals of their organizations exert efforts in pursuing the goals and achieve better economic and social outcomes.

\subsection{Bridging social capital and cooperative performance}

The influence of bridging social capital on various aspects of cooperative performance varies. The chairperson's rich "Guanxi" with downstream buyers enhances a cooperative's identity rating, yet exhibits negative influence on common members' economic performance. There is always a tradeoff between the economic goals and social influence for cooperative enterprises due to their dual objectives. Cooperatives attach more importance to member services and member satisfaction in early stages of their development and tend to lose member focus and become more economic-oriented later on (Nilsson et al., 2012). The links between 
cooperatives and buyers provide safety for members within the network, yet meanwhile may reduce flexibility and diversity, which therefore forms a tradeoff (Gargiulo and Benassi, 2000). On the one hand, long-term relationships with buyers reduce transaction costs such as information searching and negotiation costs. Risks of opportunities behaviors are lowered as well. On the other hand, opportunities for better economic pursuit are missed if cooperatives transact with fixed partners. In addition, costs occur in order to identify, develop, and maintain relationships with others (McFadyen and Cannella, 2004). Liang et al. (2015a) find a positive relationship between social capital and revenue of cooperatives. That is to say, although various social capital dimensions may contribute to the increase of revenue, it affects alternatively on common members' income. Chairpersons' close links with more buyers may reveal an orientation towards organizational level benefits over member interests.

Broad "Guanxi" of chairpersons with bank staffs is positively associated with the net profit of cooperatives. Cooperatives traditionally suffer from shortage of financial capital due to the member patronage principle (Chaddad and Cook, 2004). Nowadays cooperatives either search for investment from non-member investors or appeal to financial organizations in order to obtain additional capital. Farmer cooperatives in China are characterized by that initial physical capital is contributed mainly by a few core members, while most common members hardly pay patronage (Liang et al., 2015b). Further investment and development of cooperatives are therefore restrained because of the limited sources of capital. However, a loan from financial organizations is difficult because of the collective ownership of cooperatives and the lack of public listing (Feng and Hendrikse, 2012). Fixed assets of cooperatives are not easy to be evaluated. Neither the property rights of assets are clearly defined. Hence, the availability of a cooperative to loans is largely dependent on the private "Guanxi" between the chairperson (as well as other managers) and bank staffs. The more bank staffs the chairperson have links with, the more chances that loans are obtained.

A cooperative chairperson's good "Guanxi" with officials from the governments is positively related to net profit and identity rating. The governments play an important role in the initiation and development of farmer cooperatives in China (Jia et al., 2012; Liang and Hendrikse, 2013). Chairpersons put a lot of effort in creating "Guanxi" with the governments in order to gain "convenience" in various activities such as trademark registration, product certification, and so on. All of these activities need permissions from corresponding governmental departments. Funding support from the governments is also one of the key enticements that drive chairpersons to build and maintain good "Guanxi" with the governments. The close "Guanxi" with the government therefore generates economic benefits and good social performance outcomes for cooperatives.

Various social capital indicators which benefit cooperatives' revenue does not necessarily increases members' income. It is quite different from cooperatives in western world and worth a discussion. Valentinov (2004) stresses that the social capital decreases the transaction cost in the market and increases the well-being of their members. The subsequent empirical research, such as Nilsson (2012) and Ruben and Heras (2012) confirms that social capital brings benefits to cooperatives, which is equivalent to the whole membership. However, cooperatives in China are faced with such a paradox that bridging social capital prospers the cooperative whereas exhibits no significant benefit or even negative economic consequence on common members. Liang et al. (2015b) point out that core members dominant in both control and income rights while the common members hardly takes part in decision making. This member heterogeneity may explain the cooperative social capital's paradox in China, because it implies that common members' interests, unlike core members', are not bound up with the profit of cooperatives. Social capitals' positive influences on cooperatives' revenue, therefore, do not always benefit members.

For other characteristics, cooperatives located in Heibei have higher net profit than cooperative in Zhejiang, which may result from that cooperatives in Hebei widely use greenhouses and improve both quality and quantity of vegetables. Generally elder chairpersons perform better than younger ones in increasing cooperatives' net profit, which implies that management experiences help the development of cooperatives. Older cooperatives increase members' income and has a higher identity rating than the younger, because a long history shows that the cooperative can steadily serve its members in the long run. Chairpersons' education is positively 
associated with the cooperative's identity rating, while exhibits a negative effect on members' income increase. Well-educated chairpersons are good at learning government documents and they establish cooperatives according with the identity rating standards so as to obtain funds and supports from government. However, when chairpersons, one of the core members, pay much attention on getting resources outside, they may ignore the welfare of common members in the cooperative. Cooperatives adopting "one person one vote" decision-making rule tend to have lower identity ratings than "one share one vote" and hybrid rules. It may because the conventional "one person one vote" rule is less inefficient in making decisions such as increasing scale, standardizing production and getting brands and certificates. The low decision-making efficiency makes the cooperative grow slowly and be defeated in the identity rating competition.

\subsection{Policy implications}

Our analysis arrives at three major implications. First, it is basically beneficial to develop and nurture bonding social capital, i.e. communication, trust, and awareness of a common goal, within cooperatives to gain a better outcome. The level of bonding social capital may decline as cooperatives become larger and more complex. Inadequacies of bonding social capital tend to cause opportunistic behaviors. The market orientation of cooperatives can bring economic gains, yet meanwhile, the loss of social capital may outweigh the economic benefits. Hence, it is important for both managers and members to elicit efforts to maintain bonding social capital in cooperatives. Cooperatives could rely on internal governance and member education to create and enhance the magnitude of bonding social capital.

Second, limited relationships with transaction parties may be more favorable for cooperatives at current stages in China. Farmer cooperatives in China are mostly experiencing the stage of initiation and development, with limited capabilities in creating revenues and earnings. Although, market expansion is important in order to establish broad networks for future business, cooperatives are not powerful yet to maintain many links with buyers. Besides, it is possible that the dominant position of the chairperson or a few core members obtain most benefits from the transactions based on "Guanxi" network.

Third, given the important role of the government in cooperative development in China, effort in the "Guanxi" with the government is valued. Nevertheless, the government needs to be neutral and fair, rather than provide preferential support to cooperatives with good "Guanxi". Otherwise, it may cause corruption and over investment of cooperatives in seeking for connection with the government, which consequently results in low efficiency and hurts economic benefits of cooperatives.

\section{Conclusions and future research}

This paper conducts an exploratory analysis on the role of social capital in influencing both economic and social performance of farmer cooperatives based on a sample of 156 farmers from 54 vegetable cooperatives in China's Hebei and Zhejiang provinces. Social capital is distinguished into bonding and bridging dimensions. Bonding social capital is illustrated by technology and market information sharing, trust, and members' awareness of common goals in this paper. Bridging social capital refers to the "Guanxi" possessed by chairpersons of cooperatives and is measured by the number of chairpersons' links with input suppliers, product buyers, and bank staffs, and the closeness with the government. Due to the dual goals of cooperatives in terms of both economic and social dimensions and at both organizational and farmer levels, we look at the impacts of social capital on various performance aspects, i.e. members' income increase, cooperatives' net profit, and cooperatives' identity rating, representing member economic, cooperative economic and social performances respectively.

The statistical results display that specific dimensions of social capital may not deliver the benefits expected by cooperative practitioners and academics. Both positive and negative effects of social capital on performances of farmer cooperatives are observed. Bonding social capital is positively associated with common members' economic benefits. Bridging social capital generates beneficial outcomes for the financial and social 
performances of cooperatives while exhibits negative influence on common members' income increase, which may be due to member heterogeneity.

There are a couple of possibilities for future research. First, there may be scope for improving the evaluation of social capital because there is no standardized method yet to measure social capital. The measure of bridging social capital in the current paper is based on feedbacks from chairpersons, while bonding dimension basically from members. The integration of responses from both managers and members are desirable. Second, the impact of social capital on performance is not static and may vary along the lifecycle of cooperatives. It is of interests to look at the functions of social capital at different development stages of farmer cooperatives.

\section{Acknowledgements}

This research is supported by the National Natural Science Foundation of China (Grant No. 71573227, Grant No. 71333011), the Zhejiang Planning Office of Philosophy and Social Science (Grant No. 17NDJC93YB), and National Planning Office of Philosophy and Social Science (Grant No. 14CJY042).

\section{References}

Abebaw, D. and M.G. Haile. 2013. The impact of cooperatives on agricultural technology adoption: empirical evidence from Ethiopia. Food Policy 38: 82-91.

Adler, P.S. and S. Kwon 2002. Social capital: prospects for a new concept. Academy of Management Review 27(1): 17-40.

Arregle, J.L. and M.A. Hitt, D.G. Sirmon and P. Very 2007. The development of organizational social capital: attributes of family firms. Journal of Management Studies 44(1): 73-95.

Banaszak, I. 2008. Determinants of successful cooperation in agricultural market: evidence from producer groups in Poland. Strategy and Governance of Networks. Physical-verlag, Heidelberg, Germany.

Belliveau, M.A. and C.A. O'Reilly and J.B. Wade. 1996. Social capital at the top: effects of social similarity and status on CEO compensation. Academy of Management Journal 39(6): 1568-1593.

Bernard, T., A.S. Taffesse and E.Z. Gabre-Madhin. 2008. Impact of cooperatives on smallholders' commercialization behavior: evidence from Ethiopia. Agricultural Economics 39: 147e161.

Burt, R.S. 1992. Structural holes: the social structure of com-petition. Harvard University Press, Cambridge, MA, USA.

Chaddad, F.R. and M.L. Cook 2004. Understanding new cooperative models: an ownership-control rights typology. Review of Agricultural Economics 26(3): 348-360.

Cohen, D. and L. Prusak .2001. In good company: how social capital makes organizations work (Vol. 15). Harvard Business School Press, Boston, MA, USA.

Coleman, J.S. 1988. Social capital in the creation of human capital. American Journal of Aociology: S95-S120.

Cook, M.L. 1995. The future of US agricultural cooperatives: a neo-institutional approach. American Journal of Agricultural Economics 77(5): 1153-1159.

Cooke, P., N. Clifton and M. Oleaga. 2005. Social capital, firm embeddedness and regional development. Regional Studies 39(8): 1065-1077.

Cooke, P. and D. Wills 1999. Small firms, social capital and the enhancement of business performance through innovation programmes. Small Business Economics 13(3): 219-234.

Dejene, E. and D.G. Regasa. 2015. Factors affecting success of agricultural marketing cooperatives. International Journal of Cooperative Studies 4(1): 9-17.

Dunn, J.R. 1988. Basic cooperative principles and their relationship to selected practices. Journal of Agricultural Cooperation 3: 83-93.

Edelman, L.F., M. Bresnen, S. Newell, H. Scarbrough and J. Swan. 2004. The benefits and pitfalls of social capital: empirical evidence from two organizations in the United Kingdom. British Journal of Management 15(S1): S59-S69.

Eklinder-Frick, J., L.T. Eriksson and L. Hallén. 2011. Bridging and bonding forms of social capital in a regional strategic network. Industrial Marketing Management, 40(6): 994-1003. 
Eklinder-Frick, J., L.T. Eriksson and L. Hallén. 2012. Effects of social capital on processes in a regional strategic network. Industrial Marketing Management, 41(5): 800-806.

Feng, L. and G.W.J. Hendrikse. 2012. Chain interdependencies, measurement problems and efficient governance structure: cooperatives versus publicly listed firms. European Review of Agricultural Economics 39(2): 241-255.

Florin, J. and M. Lubatkin and W. Schulze. 2003). A social capital model of high-growth ventures. Academy of Management Journal 46(3): 374-384.

Franken, J. and M.L. Cook. 2015. Informing measurement of cooperative performance. In: Interfirm Networks, edited by J. Windsperger, G. Cliquet, T. Ehrmann and G. Hendrikse. Springer International Publishing, Basel, Switzerland.

Fulton, M. 1999. Cooperatives and member commitment. LTA 4(99): 418-437.

Gargiulo, M. and M. Benassi. 1999. The dark side of social capital. In: Corporate social capital and liability, edited by R.Th.A.J. Leenders and S.M. Gabbay. Kluwer, Boston, MA, USA, pp. 298-322.

Gargiulo, M. and M. Benassi. 2000. Trapped in your own net? Network cohesion, structural holes, and the adaptation of social capital. Organization Science 11(2): 183-196.

Granovetter, M. 1985. Economic action and social structure: the problem of embeddedness. American Journal of Sociology 91: 481-510.

Gulati, R. 1995. Does familiarity breed trust? The implications of repeated ties for contractual choice in alliances. Academy of Management Journal 38: 85-112.

Hanses, G.D. 1993. The cyclical and secular behavior of the labour input: comparing efficiency units and hours worked. Journal of Applied Econometrics 8(1): 71-80.

Hayami, Y. 2009. Social capital, human capital and the community mechanism: toward a conceptual framework for economists. Journal of Development Studies 45(1): 96-123.

Huang, Z., J. Zhang and Z. Chen. 2008. Value chain analysis of peer industry in China. Chinese Rural Economy 7: 63-72.

Ito, J., Z. Bao and Q. Su. 2012. Distributional effects of agricultural cooperatives in China: exclusion of smallholders and potential gains on participation. Food Policy 37: 700-709.

Jia, F. and G.A. Zsidisin. 2014. Supply relational risk: what role does Guanxi play? Journal of Business Logistics 35(3): 259-267.

Jia, X., J. Huang, Z. Xu. 2012. Marketing of farmer professional cooperatives in the wave of transformed agrofood market in China. China Economic Review 23(3): 665-674.

Knack, S. and P. Keefer. 1997. Does social capital have an economic payoff? A cross-country investigation. The Quarterly Journal of Economics 112(4): 1251-1288.

Leana, C.R. and F.K. Pil. 2006. Social capital and organizational performance: evidence from urban public schools. Organization Science 17(3): 353-366.

Liang Q., G. Hendrikse, Z. Huang and X. Xu. 2015b. Governance structure of Chinese farmer cooperatives: evidence from Zhejiang province. Agribusiness 31(2): 198-214.

Liang, Q. and G. Hendrikse. 2013. Core and common members in the genesis of farmer cooperatives in China. Managerial and Decision Economics 34(3-5): 244-257.

Liang, Q., Z. Huang, H. Lu and X. Wang. 2015a. Social capital, member participation, and cooperative performance: evidence from China's Zhejiang. International Food and Agribusiness Management Review 18(1): 49.

Lins, K.V., H. Servaes and A. Tamayo. 2017. Social capital, trust, and firm performance: the value of corporate social responsibility during the financial crisis. The Journal of Finance, 72(4): 1785-1824.

Locke, E.A., N.G. Noorderhaven, J.P. Cannon, P.M. Doney and M.R. Mullen. 1999. Some reservations about social capital. Academy of Management Review 24(1): 8-11.

Malecki, E.J. 2012. Regional social capital: why it matters. Regional Studies 46(8): 1023-1039.

Markelova, H., R. Meinzen-Dick, J. Hellin and S. Dohrn. 2009. Collective action for smallholder market access. Food policy 34(1): 1-7.

McFadyen, M.A. and A.A. Cannella. 2004. Social capital and knowledge creation: diminishing returns of the number and strength of exchange relationships. Academy of Management Journal 47(5): 735-746. 
Nahapiet, J. and S. Ghoshal. 1998. Social capital, intellectual capital, and the organizational advantage. Academy of Management Review 23(2): 242-266.

Nilsson, J., G.L. Svendsen and G.T. Svendsen. 2012. Are large and complex agricultural cooperatives losing their social capital? Agribusiness 28(2): 187-204.

Pearson, A.W., J.C. Carr and J.C. Shaw. 2008. Toward a theory of familiness: a social capital perspective. Entrepreneurship Theory and Practice 32(6): 949-969.

Pennings, J.M., K. Lee and A. Van Witteloostuijn. 1998. Human capital, social capital, and firm dissolution. Academy of Management Journal 41(4): 425-440.

Portes, A. 2014. Downsides of social capital. Proceedings of the National Academy of Sciences of the USA 111(52): 18407-18408.

Portes, A. and J. Sensenbrenner. 1993 Embeddedness and immigration: notes on the social determinants of economic action. American Journal of Sociology 98(6): 1330-1350.

Putnam, R.D. 1995. Bowling alone: America's declining social capital. Journal of Democracy 6(1): 65-78.

Raub, W. and J. Weesie. 1990. Reputation and efficiency in social interactions: an example of network effects. American Journal of Sociology 96: 626-654.

Robison, L.J., A.A. Schmid and E.S. Marcelo. 2002. Is social capital really capital? Review of Social Economy 60(1): 1-21.

Ruben, R. and J. Heras. 2012. Social capital, governance and performance of Ethiopian coffee cooperatives. Annals of Public and Cooperative Economics 83(4): 463-484.

Schiele, H., S.C. Ellis, M. Eßig, J.W. Henke and T.J. Kull. 2015. Managing supplier satisfaction: Social capital and resource dependence frameworks. Australasian Marketing Journal, 23(2): 132-138.

Semrau, T. and C. Hopp. 2016. Complementary or compensatory? A contingency perspective on how entrepreneurs' human and social capital interact in shaping start-up progress. Small Business Economics: 46(3): 407-423.

Sexton, R. and J. Iskow. 1988. Factors critical to success or failure of emerging agricultural cooperatives. Giannini Foundation Information series No. 88(3).

Song, Y. and R. Vernooy 2010. Seeds and synergies: innovating rural development in China, practical action publishing and international development research centre. Rugby, Ottawa, Canada.

Søgaard, V. 1994. Farmers, cooperatives, new food products. Mapp, Aarhus School of Business, Aarhuus, Denmark.

Staatz, J.M. 1987. Farmers' incentives to take collective action via cooperatives: a transaction cost approach. Cooperative Theory: New Approaches 18: 87e107.

Tsai, W. and S. Ghoshal. 1998. Social capital and value creation: the role of intrafirm networks. Academy of Management Journal 41(4): 464-476.

Valentinov, V. 2004. Toward a social capital theory of cooperative organisation. Journal of Cooperative Studies 37(3): 5-20.

Weber, C. and B. Weber. 2011. Exploring the antecedents of social liabilities in CVC triads - A dynamic social network perspective. Journal of Business Venturing, 26(2): 255-272.

Westlund, H. and M. Gawell. 2012. Building social capital for social entrepreneurship. Annals of Public and Cooperative Economics 83(1): 101-116.

Yang, H., X. Klerkx and C. Leeuwis. 2013. Functions and limitations of farmer cooperatives as innovation intermediaries: Findings from China. Agricultural Systems 127: 115-125. 